\title{
Clinical features and treatment outcomes of patients with Hodgkin lymphoma: A single-center study of 36 cases
}

\author{
Kiyotaka Izumi $^{*}$, Yoshimasa Kamoda ${ }^{1}$, Futoshi Iioka ${ }^{1}$, Yoshitomo Maesako ${ }^{1}$, Takashi Akasaka ${ }^{1}$, \\ Gen Honjo ${ }^{2}$, Hitoshi Ohno ${ }^{1}$
}

${ }^{1}$ Department of Hematology, Tenri Hospital; ${ }^{2}$ Department of Diagnostic Pathology, Tenri Hospital

Received 2014/2/24; accepted 2014/5/29; released online 2014/7/1

Purpose: The aim of this study was to clarify clinical features and treatment outcomes of patients with Hodgkin lymphoma $(\mathrm{HL})$ in our institution.

Patients: The study included $36 \mathrm{HL}$ patients who were treated with chemotherapy alone or in combination with radiotherapy from January 2003 to October 2012.

Results: Twenty-four patients had nodular sclerosis and 6 had the mixed cellularity subtype. The age ranged from 20 to 81 , with a median of 61 , and 18 patients were aged 60 or older. Eight patients had localized disease, while 28 fell into the advanced disease category. According to the international prognosis scoring scheme, 14 and 22 patients had disease with a favorable and an unfavorable prognosis, respectively. Twenty-nine patients were initially treated with ABVd/ABVD combination chemotherapy and 7 received planned radiotherapy. Twenty-three (63.9\%) patients achieved a complete response, and the overall response rate was $72.2 \%$. Two treatment-related deaths occurred. At a median follow-up of 3.0 years, the estimated 5-year progression-free survival (PFS) and overall survival (OS) rates were 66.1 and $75.0 \%$, respectively. The survival in elderly patients aged $\geq 60$ was inferior to that of younger patients aged $<60$ ( 5 year PFS rate, 54.7 vs. $76.2 \%$; 5 -year OS rate, 55.0 vs. $94.1 \%$, respectively, $P=0.014$ ), presumably due to significant comorbidities and treatment toxicities.

Conclusion: The outcomes of younger HL patients were comparable to those of the JCOG 9305 study. At present, $A B V D$ is suggested for most elderly patients with $\mathrm{HL}$, but more tolerable and less toxic regimens should be developed for this particular HL population.

Keywords: Hodgkin lymphoma, $A B V d / A B V D$ combination chemotherapy, treatment outcome, elderly patients, JCOG 9305 study

\section{INTRODUCTION}

Hodgkin lymphoma (HL) is a heterogeneous group of tumors characterized by the presence of a minority of neo-

*Correspondence to: Kiyotaka Izumi, MD Department of Hematology, Tenri Hospital 200 Mishima, Tenri, Nara 632-8552, Japan

e-mail: k-izumi@tenriyorozu.jp plastic Reed-Sternberg cells in an inflammatory background. ${ }^{1}$ HL was reported by the Lymphoma Study Group of Japanese Pathologists to comprise 4.41\% (141 patients) of all lymphomas (3,194 patients) in Japan diagnosed between 1994 and $1996,{ }^{2}$ while the percentage in the United States was $11.4 \%$ (8,510 of 74,490 patients). ${ }^{3}$ Accounting, in part, for this lower incidence of HL in Japan than in 
Western countries, there have been few prospective studies addressing the efficacy and safety of specific treatments for Japanese HL patients.

With the use of combination chemotherapy for the treatment of HL since the 1960s, the disease has been converted from incurable to curable in nearly $75 \%$ of patients worldwide. ${ }^{4}$ The ABVD regimen, which was introduced in the mid-1970s in Europe and the United States, consists of $25 \mathrm{mg} / \mathrm{m}^{2}$ doxorubicin, $10 \mathrm{mg} / \mathrm{m}^{2}$ bleomycin, 6 $\mathrm{mg} / \mathrm{m}^{2}$ vinblastine, and $375 \mathrm{mg} / \mathrm{m}^{2}$ dacarbazine. ${ }^{5}$ The $\mathrm{ABVd}$ regimen, on the other hand, consisting of $25 \mathrm{mg} / \mathrm{m}^{2}$ doxorubicin, $9 \mathrm{mg} / \mathrm{m}^{2}$ (maximum $15 \mathrm{mg}$ ) bleomycin, $6 \mathrm{mg} / \mathrm{m}^{2}$ (maximum $10 \mathrm{mg}$ ) vinblastine, and $250 \mathrm{mg} / \mathrm{m}^{2}$ dacarbazine, was developed by the Lymphoma Study Group of the Japan Clinical Oncology Group (JCOG-LSG) in 1989, in combination with alternating the c-MOPP (cyclophosphamide, vincristine, procarbazine, and prednisolone) regimen (JCOG 8905 study). ${ }^{6}$ The dose of dacarbazine was determined to prevent severe gastrointestinal symptoms caused by this high emesis-risk agent. After the subsequent phase II study of ABVd alone for newly diagnosed clinical stage II-IV HL (JCOG 9305) patients between 1993 and 1997, in which the CR rate was $81.4 \%$, and PFS and OS at 5 years were 78.4 and $91.3 \%$, respectively, ABVd had become the treatment of choice for Japanese HL patients before the official publication in 2010. ${ }^{7}$ Nevertheless, as effective anti-emesis medications have become available, the dose of $375 \mathrm{mg} / \mathrm{m}^{2}$ dacarbazine is currently tolerable in Japanese HL patients. In the guidelines of the Japan Society of Hematology, ABVD is the standard chemotherapy for both localized and advanced HL. ${ }^{8}$

In this study, we investigated clinical features and treatment outcomes of a total of 36 patients who were diagnosed with $\mathrm{HL}$ and treated in our institution over the last 10 years.

\section{PATIENTS AND METHODS}

\section{Patients}

Between January 2003 and October 2012, a total of 40 patients who were first admitted to our institution with a diagnosis of HL were registered in the Clinical Record Management Unit. As three patients were not definitively diagnosed with HL according to the pathology reports and one patient declined therapy, the remaining 36 patients were included in this retrospective cohort study. We reviewed their clinical records from both inpatient and outpatient departments, and obtained information regarding clinical parameters, laboratory data, imaging studies, treatments, and outcomes.

The disease was staged I through IV according to the Ann Arbor classification with the Cotswolds modification scheme on the basis of clinical, radiological, and pathological (i.e., bone marrow examination) criteria. ${ }^{9}$ Bulky disease was defined by the presence of a mass of $\geq 10 \mathrm{~cm}$ in largest diameter as determined by computed tomography (CT). "B" symptoms consisted of $\geq 10 \%$ body weight loss over the last 6 months, unexplained fever of $\geq 38^{\circ} \mathrm{C}$, and night sweats. Suffix "A" indicates the absence of B symptoms. Stage I and IIA diseases lacking a bulky tumor were classified in the localized disease category, while stage IIA with a bulky tumor, IIB, III, and IV diseases were in the advanced disease category. ${ }^{7}$ Seven risk factors included in the International Prognostic Score (IPS) were: serum albumin $<4 \mathrm{~g} / \mathrm{dL}$, hemoglobin $<10.5 \mathrm{~g} / \mathrm{dL}$, male sex, age $>45$ years, stage IV disease, white blood cell count $\geq 15,000 / \mu \mathrm{L}$, and absolute lymphocyte count $<600 / \mu \mathrm{L}$ and/ or $<8 \%$ of the total white blood cell count.9 We applied IPS for all patients studied, even though it was originally developed for advanced HL.

\section{Response Assessment and Survival Analysis}

Complete remission, unconfirmed/uncertain CR (CRu), partial remission (PR), stable disease (SD), and relapse/ progressive disease (PD) were as defined at the 1989 Cotswolds meeting and by the 1999 International Workshop to Standardize Response Criteria for Non-Hodgkin Lymphoma. ${ }^{10,11}$ Since positron emission tomography (PET) was available in our institution in 2006, PET-based response assessment was introduced according to the 2007 Revised Response Criteria for Malignant Lymphoma. ${ }^{12}$ 
Progression-free survival was defined as the interval from the date of the first chemotherapy to the date of disease progression, including relapse after CR, or death from any cause. Overall survival was calculated from the date of the first chemotherapy to death from any cause. Survival estimates were computed by the Kaplan-Meier log-rank test. Data were censored on the date of the last follow-up visit. Statistical analysis was carried out with StatViewC.

\section{RESULTS}

\section{Patient Characteristics}

The pathological and pre-treatment clinical characteristics of the 36 patients are summarized in Table 1. The nodular sclerosis and mixed cellularity subtypes accounted for 66.6 and $16.7 \%$, respectively, while the subtype of $13.9 \%$ of cases was not specified. The median age was 61 years, and 18 patients were aged 60 or older. The age distribution showed a bimodal curve (Figure 1); there was one peak at 20-29 years old and another peak at 6069 years old. Mixed cellularity histopathology was present in patients aged $\geq 40$. The male-to-female ratio was 26:10. Comorbidities included cardiovascular diseases, pulmonary diseases, and diabetes mellitus, in addition to other non-significant conditions. B symptoms were present in $20(55.6 \%)$ patients at the initial presentation. The ECOG performance status (PS) was 0 or 1 in 33 (91.6\%) patients. Bulky disease was present in 3 patients (8.3\%). Eight (22.2\%) patients had localized disease, while 28 (77.8\%) fell into the advanced disease category. According to the IPS risk stratification, 14 (38.9\%) and 22 (61.1\%) patients had disease with a favorable (risk score, 0 to 2 ) and an unfavorable (risk score, 3 or more) prognosis, respectively.

\section{Treatment and Outcome}

Twenty-four (66.6\%) patients were initially treated with the $\mathrm{ABVd}$ regimen consisting of a reduced dose of dacarbazine (Table 2). Standard-dose ABVD was given to 5 patients (13.8\%). The numbers of ABVd/ABVD cycles for localized (7 patients) and advanced disease (22 pa-
Table 1. Patient characteristics

\begin{tabular}{|c|c|c|c|}
\hline Characteristics & & $\begin{array}{l}\text { No. } \\
\text { of patients }\end{array}$ & $\%$ \\
\hline \multirow[t]{4}{*}{ Histopathology } & Nodular sclerosis & 24 & 66.6 \\
\hline & Mixed cellularity & 6 & 16.7 \\
\hline & Lymphocyte-rich & 1 & 2.8 \\
\hline & Undetermined & 5 & 13.9 \\
\hline \multirow[t]{2}{*}{ Age (years) } & Median & \multicolumn{2}{|l|}{61} \\
\hline & Range & \multicolumn{2}{|l|}{$20-81$} \\
\hline \multirow[t]{2}{*}{ Gender } & Male & 26 & 72.2 \\
\hline & Female & 10 & 27.8 \\
\hline \multirow[t]{2}{*}{ Comorbidities } & Present & 19 & 52.8 \\
\hline & Absent & 17 & 47.2 \\
\hline \multirow[t]{5}{*}{ Performance status } & 0 & 16 & 44.4 \\
\hline & 1 & 17 & 47.2 \\
\hline & 2 & 2 & 5.6 \\
\hline & 3 & 1 & 2.8 \\
\hline & 4 & 0 & 0 \\
\hline \multirow{8}{*}{$\begin{array}{l}\text { Ann Arbor/Cotswold } \\
\text { clinical stage }\end{array}$} & I & 3 & 8.3 \\
\hline & II & 10 & 27.8 \\
\hline & IIA, non-bulky & 5 & 13.9 \\
\hline & IIA, bulky; IIB & 5 & 13.9 \\
\hline & III & 14 & 38.9 \\
\hline & IV & 9 & 25.0 \\
\hline & B symptoms & 20 & 55.6 \\
\hline & Bulky tumor & 3 & 8.3 \\
\hline \multirow{8}{*}{$\begin{array}{l}\text { International } \\
\text { prognostic score }\end{array}$} & 0 & 1 & 2.8 \\
\hline & 1 & 10 & 27.8 \\
\hline & 2 & 3 & 8.3 \\
\hline & 3 & 14 & 38.9 \\
\hline & 4 & 4 & 11.1 \\
\hline & 5 & 3 & 8.3 \\
\hline & 6 & 0 & 0 \\
\hline & 7 & 1 & 2.8 \\
\hline
\end{tabular}

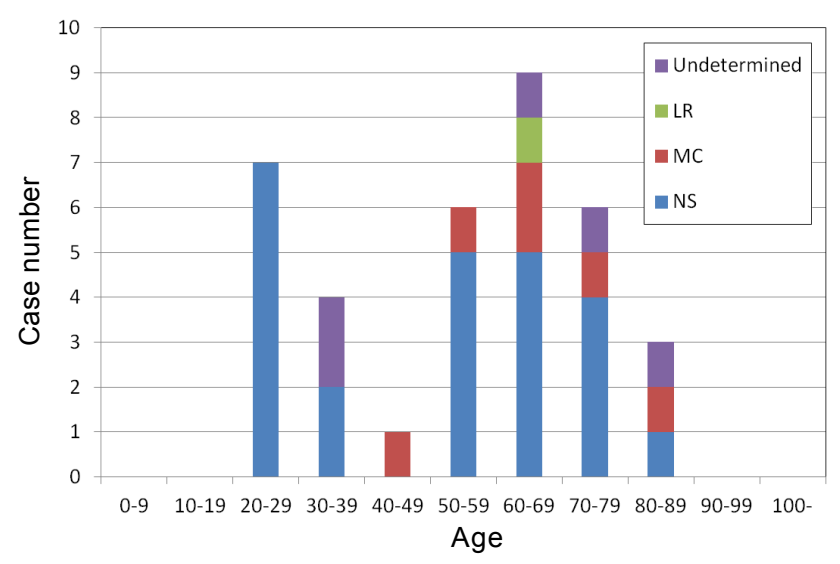

Figure 1. Age distribution of $\mathbf{3 6}$ patients with Hodgkin lymphoma.

NS, nodular sclerosis; MC, mixed cellularity; LR, lymphocyte-rich. 
tients) were 2 to 8 (median, 4) and 1.5 to 8 (median, 6), respectively. Other regimens were selected for individual patients, in whom cardiopulmonary toxicities of doxorubicin and bleomycin were considered to be avoided. Seven patients received planned radiotherapy following chemotherapy.

Patients were classified based on the best tumor response to the initial treatment (Table 3). Twenty-three (63.9\%) and 3 patients (8.3\%) achieved CR and PR, respectively; the overall response rate $(\mathrm{CR}+\mathrm{PR})$ was $72.2 \%$. Four patients $(11.1 \%)$ had SD after the initial treatment, and progression during treatment occurred in 6 patients (16.7\%). Two CR patients had relapsed disease. Of the 12 $\mathrm{SD} / \mathrm{PD}$ patients, 7 received second-line chemotherapies, including DeVIC (dexamethasone, etoposide, ifosfamide, and carboplatin) and DHAP regimens (dexamethasone, cytarabine, and cisplatin). One patient who was refractory to the initial and salvage treatments underwent allogeneic stem cell transplantation using a graft from an HLAmatched sibling donor. Two SD patients were treated with salvage treatments followed by high-dose chemotherapy with the support of autologous stem-cell transplantation, finally achieving CR. No second cancer developed during the study period.

\section{Survival}

At a median follow-up of 3.0 years, 11 patients had relapse/disease progression and 8 died. The estimated 5 year PFS and OS rates were 66.1 and $75.0 \%$, respectively (Figures 2A and 3A). We stratified the patients according to age $<60(n=18)$ vs. $\geq 60(n=18)$, localized $(n=8)$ vs. advanced disease $(n=28)$, and IPS favorable $(n=14)$ vs. unfavorable disease $(n=22)$, and compared the survival of each risk group. As shown in Figures 2 and 3, patients aged $<60$, with localized disease, and in the IPS favorable category showed a tendency toward better PFS and OS than those of each counterpart, and the difference in OS between age $<60$ and $\geq 60$ patients was significant $(P=$ 0.014). The estimated PFS and OS rates for the age $<60$ group at both 3 and 5 years were 76.2 and $94.1 \%$, respec-
Table 2. Initial treatment regimen

\begin{tabular}{lcl}
\hline Regimen & $\begin{array}{l}\text { No. } \\
\text { of patients }\end{array}$ & $\%$ \\
\hline ABVd & 24 & 66.6 \\
ABVD & 5 & 13.8 \\
c-MOPP & 2 & 5.6 \\
C-MOPP/ABVd & $2^{*}$ & 5.6 \\
CHOP & 2 & 5.6 \\
THP-COP & 1 & 2.8 \\
Radiation therapy following chemotherapy & 7 & 19.4 \\
\hline
\end{tabular}

ABVd/ABVD, doxorubicin, bleomycin, vinblastine, dacarbazine; $\mathrm{CHOP}$, cyclophosphamide, doxorubicin, vincristine, prednisolone; c-MOPP, cyclophosphamide, vincristine, procarbazine, prednisolone; THP-COP, pirarubicin, cyclophosphamide, vincristine, prednisolone.

*In one patient, procarbazine was omitted.

Table 3. Response

\begin{tabular}{lll}
\hline Response & No. of patients & $\%$ \\
\hline Complete response (CR) & 23 & 63.9 \\
Partial response (PR) & 3 & 8.3 \\
Stable disease & 4 & 11.1 \\
Progressive disease & 6 & 16.7 \\
CR + PR & 26 & 72.2 \\
\hline
\end{tabular}

*Including CR unconfirmed/uncertain (CRu).

tively, while those for the age $\geq 60$ group were 54.7 and $55.0 \%$, respectively.

\section{Comparison between Age $<60$ and $\geq 60$ Patients}

To explore the cause of the poorer survival of elderly patients compared with that of younger patients, we compared pretreatment clinical parameters, comorbidities, and the treatment course between age $<60$ and $\geq 60$ patients. As shown in Table 4, there was no significant difference in PS, the proportion of localized and advanced disease, IPS risk factors except for anemia, or the presence or absence of B-symptoms. On the other hand, comorbid conditions in age $\geq 60$ patients, including cardiovascular diseases in 7, pulmonary diseases in 2, and diabetes mellitus in 5 , were more frequent than in those $<60$. Although the $\mathrm{CR}$ rates were comparable between the two age groups, 2 (16.7\%) of the $12 \mathrm{CR}$ patients in the $\geq 60$ group relapsed, while none of the CR patients in the $<60$ group did so. Two treatment-related deaths occurred in the $\geq 60$ group. 

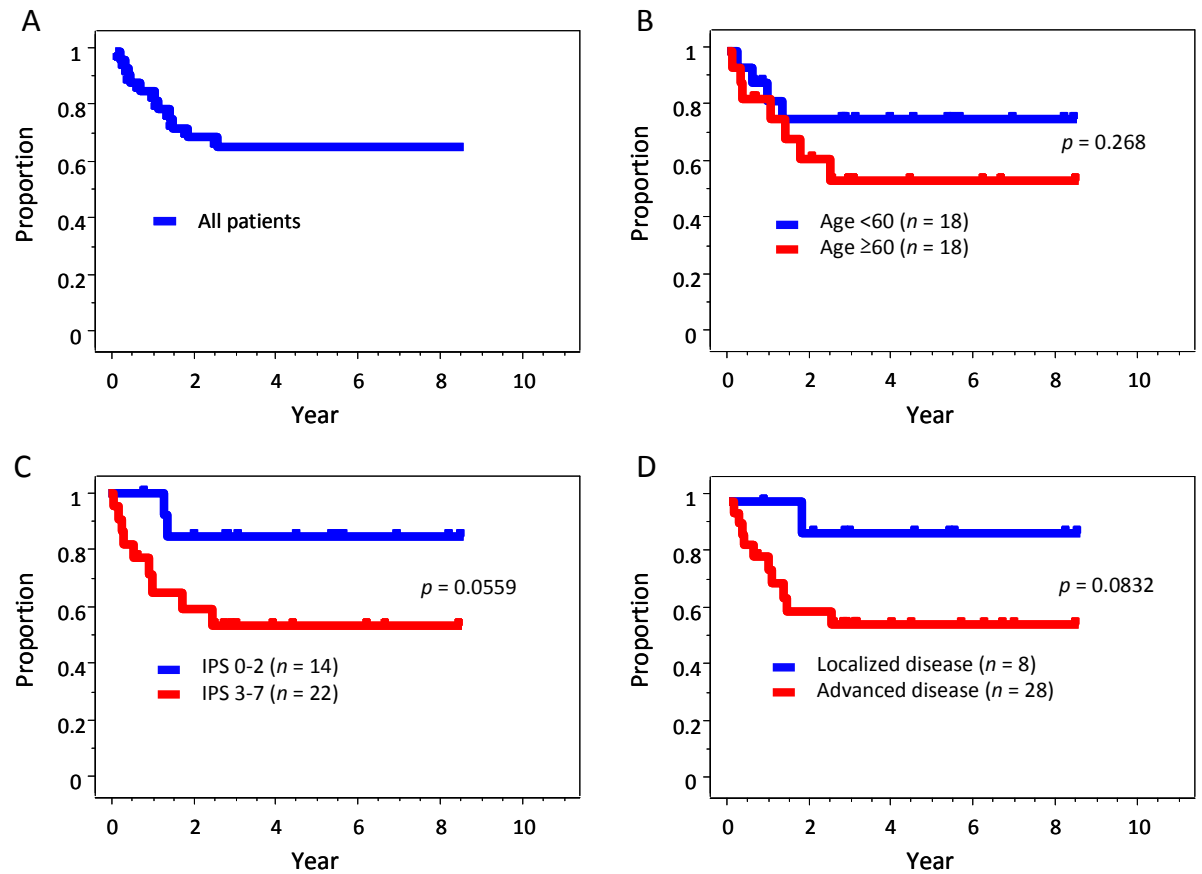

Figure 2. Kaplan-Meier curves showing progression-free survival (PFS). Tick marks indicate censored data. (A) All 36 patients. (B) Comparison between the age groups. The blue line represents patients under the age of $60(n=18)$, and the red line represents those aged 60 or older $(n=18)$. (C) Comparison between the IPS risk groups. The blue line represents a favorable disease category (IPS score, $0-2 ; n=14$ ) and the red line represents an unfavorable disease category (IPS score, $3-7 ; n=22$ ). (D) Comparison between the stages. The blue line represents localized disease (stages I and IIA lacking a bulky tumor; $n=8$ ) and the red line represents advanced disease (stage IIA with a bulky tumor, IIB, III, or IV; $n=28$ ).
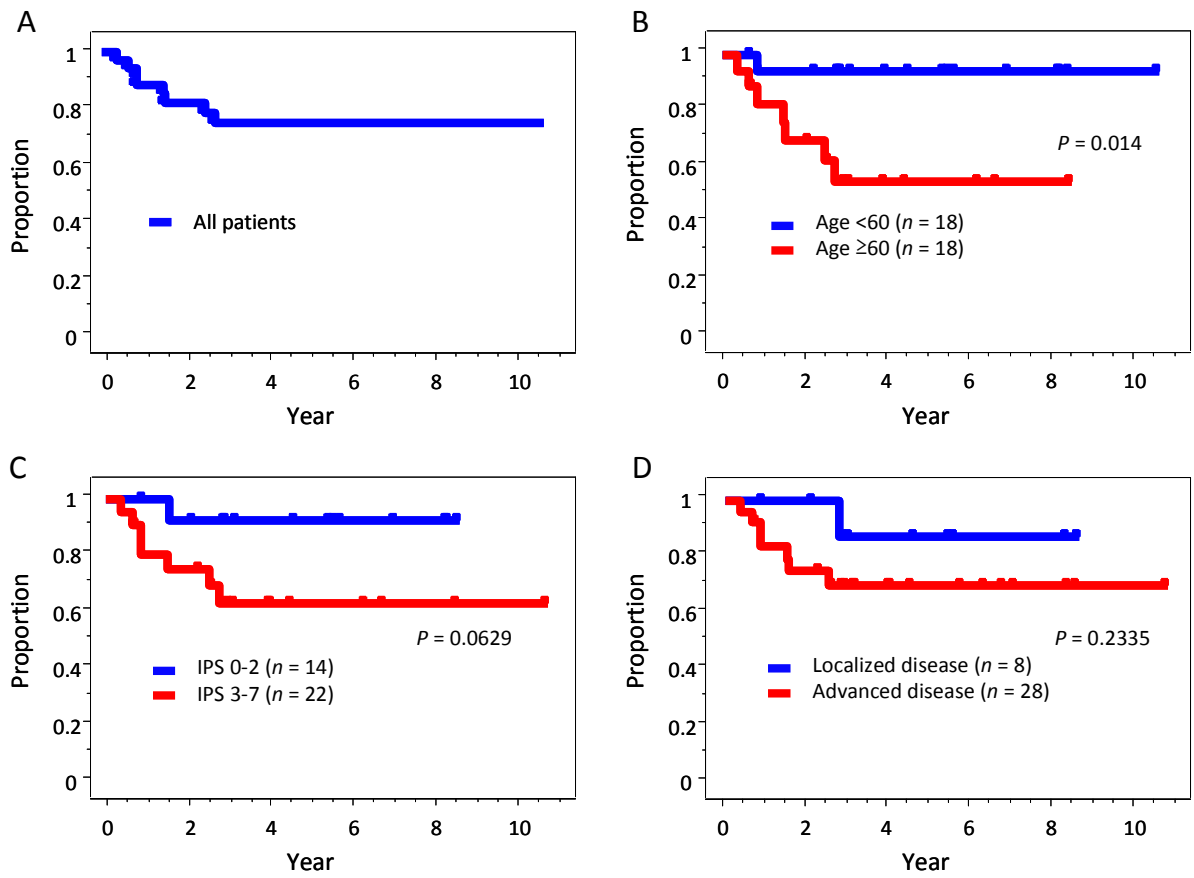

Figure 3. Kaplan-Meier curves showing overall survival (OS). Tick marks indicate censored data. (A) All 36 patients. (B) Comparison between the age $<60$ (blue line) and $\geq 60$ groups (red line). (C) Comparison between the IPS favorable (blue line) and unfavorable diseases (red line). (D) Comparison between the localized (blue line) and advanced diseases (red line). 
Table 4. Comparison between patients aged $<60$ and $>60$

\begin{tabular}{|c|c|c|c|}
\hline \multirow{2}{*}{ Characteristics } & & \multicolumn{2}{|c|}{ No. of patients } \\
\hline & & $<60(n=18)$ & $\geq 60(n=18)$ \\
\hline \multirow[t]{2}{*}{ Performance status } & 0,1 & 18 & 15 \\
\hline & $\geq 2$ & 0 & 3 \\
\hline \multirow[t]{2}{*}{ Stage of disease } & Localized & 4 & 4 \\
\hline & Advanced & 14 & 14 \\
\hline \multirow{6}{*}{$\begin{array}{l}\text { IPS risk factors (excluding } \\
\text { age) }\end{array}$} & Hypoalbuminemia & 10 & 13 \\
\hline & Anemia & 1 & 6 \\
\hline & Male gender & 11 & 15 \\
\hline & Stage IV disease & 4 & 5 \\
\hline & Leukocytosis & 2 & 1 \\
\hline & Lymphocytopenia & 1 & 2 \\
\hline \multirow[t]{2}{*}{ B symptoms } & Present & 11 & 9 \\
\hline & Absent & 7 & 9 \\
\hline \multirow[t]{2}{*}{ Comorbid conditions } & Present & $6^{*}$ & 13 \\
\hline & Absent & 12 & 5 \\
\hline \multirow{2}{*}{$\begin{array}{l}\text { Cycles of first-line treatment } \\
\text { for advanced disease }\end{array}$} & Range & $4-8$ & $1.5-8$ \\
\hline & Median & 6 & 4 \\
\hline \multirow[t]{2}{*}{ Response } & CR (\%) & 61.1 & 66.7 \\
\hline & CR + PR (\%) & 77.8 & 66.7 \\
\hline Treatment-related mortality & & 0 & 2 \\
\hline
\end{tabular}

\section{DISCUSSION}

In contrast to randomized clinical trials of HL, in which older patients (i.e., $\geq 60$ ) account for a minority of participants ${ }^{13}$ our cohort included 18 patients $(50 \%)$ aged 60 or older, and the median age was 61 . Thus, our results out of clinical trials may be discussed separately according to the age groups. For younger patients aged $<60$, PFS and OS at 5 years of 76.2 and $94.1 \%$, respectively, are comparable to those of the JCOG9305 study, in which the age ranged from 15 to 69 , with a median of $32.5 .^{7}$ Although 4 patients failed to achieve $\mathrm{CR}$ or showed $\mathrm{PD}$, all but one responded to salvage treatments with or without consolidating high-dose chemotherapy. During the study period, there was no significant long-term treatment-related morbidity or mortality in this age group.

Time- and dose-intensified regimens have been developed for younger patients aiming at more effective tumor control and improved long-term survival. The Stanford V regimen in combination with radiation therapy has the advantages over $\mathrm{ABVD}$ of a short administration schedule and reduced cumulative dose of bleomycin and doxorubicin. ${ }^{14}$ The BEACOPP (bleomycin, etoposide, doxorubicin, cyclophosphamide, vincristine, procarbazine, and prednisone) regimen, given in standard or escalated doses for advanced-stage HL patients, has been shown to provide better initial tumor control than ABVD. ${ }^{15}$ However, severe toxic events occurred more frequently in the BEACOPP-treated group, and the long-term survival did not differ significantly between the ABVD and BEACOPP groups, ${ }^{15}$ indicating that second-line treatment effectively salvaged $<\mathrm{CR}$ or PD patients after ABVD. Thus, because most HL patients of younger age are effectively treated with ABVD, as confirmed by our study, application of these two intensified regimens as the initial treatment should be confined to high-risk patients who require aggressive treatment to achieve long-term disease control.

The treatment of older HL patients has been challenging, as the response to treatment and survival of older 
populations has been shown to be significantly inferior to those of younger populations, even though a data analysis of the United States Surveillance, Epidemiology, and End Results (SEER) reported improved survival of all ages of HL patients from 1980-1984 to 2000-2004, and the improvement was particularly marked for patients aged 45 to 59 years and 60 years and older. ${ }^{16}$ We reviewed recently published clinical trials for older patients with $\mathrm{HL}$ (Table 5), ${ }^{13,17-21}$ and found that the $\mathrm{CR}$ rate ranged from 64 to $85 \%$, PFS at 5 years was 44 to $56 \%$, and OS at 5 years was 58 to $64 \%$; the outcome of our cohort seems to be inferior to those results. The low initial response rate and the high relapse rate may be among the reasons for this.

It has been proposed that the inferior outcome of older HL patients compared with that of younger patients is due to the potential biological difference in the disease itself (e.g., more aggressive behavior) or treatment toxicity or comorbidities unrelated to HL. The former possibility seems to be unlikely because there was no major difference in known prognostic factors for the response and survival between older $(\geq 60)$ versus younger $(<60)$ patients (Table 4$)$. On the other hand, 13 (72\%) of the 18 older HL patients in our cohort had comorbid conditions at diagnosis, and these patients tended to develop severe adverse events. Two patients developed bleomycin lung toxicity (BLT) during treatment and one died of the toxicity. Evens et al., in their trial to compare the efficacy and treatment tolerability between ABVD and Stanford V in older HL patients, reported that as many as $10(42 \%)$ of 24 ABVD-treated patients developed BLT and two died of the toxicity during the AVBD cycles, and the overall treatment-related mortality was $9 \% .{ }^{20}$ Another cause of the inferior outcome in elderly patients may be the difficulty in maintaining the dose and complying with the treatment schedule, as required by the protocol. In our cohort, the cycle number of first-line chemotherapy was less in older patients with advanced disease than that in the younger counterpart (Table 4), suggesting that insufficient dosing with chemotherapeutic agents was responsible for the inferior outcome.

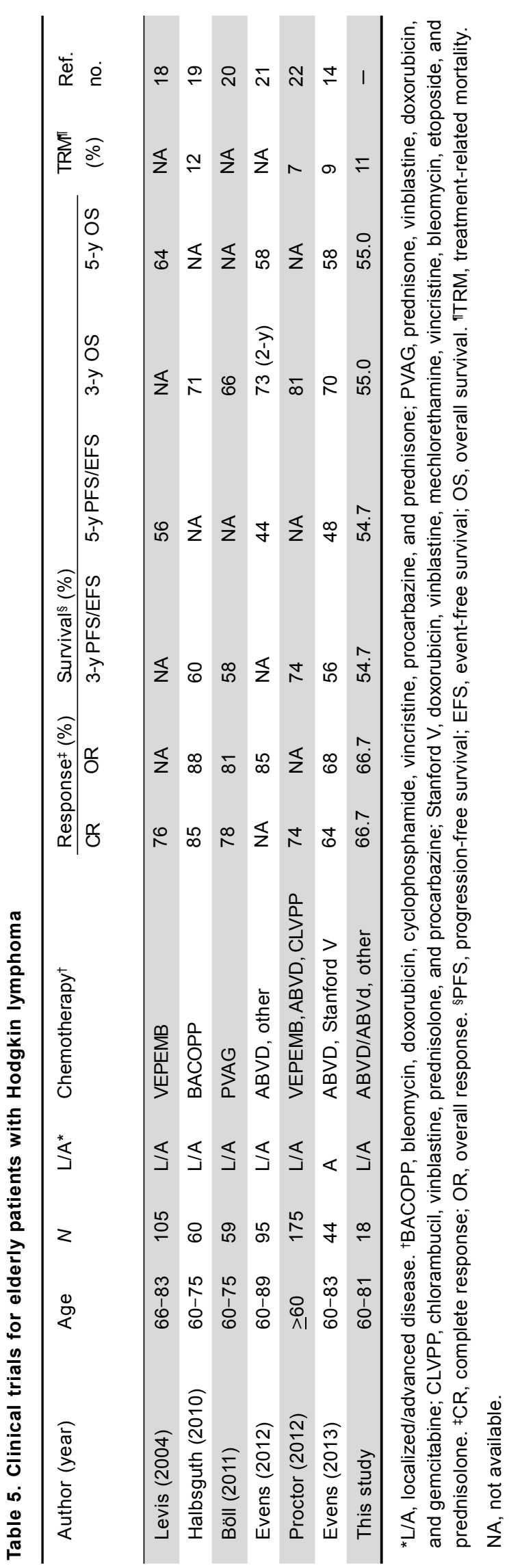


To improve both the tolerability and the efficacy of treatment for older HL patients, the German Hodgkin Study Group (GHSG) developed the BACOPP regimen, in which, compared with BEACOPP, etoposide was omitted, while the doxorubicin dose was increased. ${ }^{18}$ Of 60 patients with early unfavorable or advanced-stage HL aged between 60 and 75 years, 51 (85\%) achieved CR and the 3-year PFS and OS were 71 and 60\%, respectively (Table 5); however, this result was compromised by a $12 \%$ ( 7 of 60 ) treatmentrelated mortality rate. The GHSG next introduced gemcitabine to develop a PVAG regimen. ${ }^{19}$ In their multicenter phase II study including 59 patients aged 60 to 75 years (median, 68 years), the 3-year OS and PFS were estimated as 58 and $66 \%$, respectively (Table 5). Although grade $3 / 4$ toxicity during chemotherapy was documented in 43 patients, only one treatment-related death occurred. ${ }^{19}$ Another regimen, VEPEMB, ${ }^{17}$ was re-evaluated by the SHIELD (Study of Hodgkin in the Elderly/ Lymphoma Database) program in the United Kingdom, in which 103 patients were enrolled (median, 73 years). ${ }^{21}$ For the patients with early-stage disease, the $\mathrm{CR}$ rate was $74 \%$ and 3-year OS and PFS were 81 and 74\%, respectively, while, for patients with advanced-stage disease, the CR rate was $61 \%$ and 3-year OS and PFS were 66 and 58\%, respectively. ${ }^{21}$ The overall treatment-related mortality was reported to be $7 \%$. The authors of the latter two studies suggested that their regimens were well-tolerated by elderly HL patients; ${ }^{19,21}$ although it is premature to introduce these regimens into clinical practice, as neither of the studies demonstrated superior outcomes in a randomized trial, these regimens can be an option for relapsed or refractory patients.

Although IPS scoring is widely accepted to establish a prognosis for patients with $\mathrm{HL}$, other prognostic factors have been identified for elderly patients. In a multicenter retrospective analysis of 95 consecutive elderly HL patients (range, 60-89 years; median, 67 years), most IPS factors were non-prognostic, whereas an age over 70 years and loss of activities of daily living were significantly correlated with inferior OS by multivariate analysis. ${ }^{20} \mathrm{Al}-$ though we were not able to determine the ADL score of each patient from the clinical records, it is possible that the decision regarding the initial chemotherapy regimen and treatment schedule were largely affected by the presence of geriatric syndromes and loss of ADL, thereby leading to a poor treatment outcome.

In summary, our current retrospective study showed that the treatment outcome of younger patients with $\mathrm{HL}$ treated in our hospital was comparable to that in the JCOG study. However, the outcome in elderly patients was inferior to that of younger patients presumably due to comorbidities and treatment toxicities. At present, ABVD is suggested for most elderly patients with HL, but more tolerable and less toxic regimens should be developed for this particular HL population.

\section{REFERENCES}

1. Stein H, Delsol G, Pileri SA, et al. Classical Hodgkin lymphoma, introduction. In: Swerdlow SH, Campo E, Harris NL, et al., eds. WHO Classification of Tumours of Haematopoietic and Lymphoid Tissues. Lyon: IARC; 2008 : 326-329.

2. The world health organization classification of malignant lymphomas in japan: incidence of recently recognized entities. Lymphoma Study Group of Japanese Pathologists. Pathol Int 2000;50:696-702.

3. Jemal A, Siegel R, Ward E, et al. Cancer statistics, 2009. CA Cancer J Clin 2009;59:225-249.

4. Longo DL. Treatment of advanced Hodgkin lymphoma: the more things change, the more they stay the same. J Clin Oncol 2013;31:660-662.

5. Bonadonna G, Zucali R, Monfardini S, et al. Combination chemotherapy of Hodgkin's disease with adriamycin, bleomycin, vinblastine, and imidazole carboxamide versus MOPP. Cancer 1975;36:252-259.

6. Takenaka T, Mikuni C, Miura A, et al. Alternating combination chemotherapy C-MOPP (cyclophosphamide, vincristine, procarbazine, prednisone) and ABVd (adriamycin, bleomycin, vinblastine, dacarbazine) in clinical stage II-IV Hodgkin's disease: a multicenter phase II study (JCOG 8905). The Lymphoma Study Group of the Japan Clinical Oncology Group. Jpn J Clin Oncol 2000;30:146-152.

7. Ogura M, Itoh K, Kinoshita T, et al. Phase II study of $\mathrm{ABVd}$ therapy for newly diagnosed clinical stage II-IV 
Hodgkin lymphoma: Japan Clinical Oncology Group study (JCOG 9305). Int J Hematol 2010;92:713-724.

8. 造血器腫瘍診療ガイドライン一般社団法人 日本血液 学会編. 東京: 金原出版; 2013.

9. Hasenclever D, Diehl V. A prognostic score for advanced Hodgkin's disease. International Prognostic Factors Project on Advanced Hodgkin's Disease. N Engl J Med 1998; 339:1506-1514.

10. Cheson BD, Horning SJ, Coiffier B, et al. Report of an international workshop to standardize response criteria for non-Hodgkin's lymphomas. NCI Sponsored International Working Group. J Clin Oncol 1999;17:1244.

11. Lister TA, Crowther D, Sutcliffe SB, et al. Report of a committee convened to discuss the evaluation and staging of patients with Hodgkin's disease: Cotswolds meeting. J Clin Oncol 1989;7:1630-1636.

12. Cheson BD, Pfistner B, Juweid ME, et al. Revised response criteria for malignant lymphoma. J Clin Oncol 2007;25:579-586.

13. Evens AM, Hong F, Gordon LI, et al. The efficacy and tolerability of adriamycin, bleomycin, vinblastine, dacarbazine and Stanford V in older Hodgkin lymphoma patients: a comprehensive analysis from the North American intergroup trial E2496. Br J Haematol 2013;161:7686.

14. Horning SJ, Hoppe RT, Breslin S, et al. Stanford V and radiotherapy for locally extensive and advanced Hodgkin's disease: mature results of a prospective clinical trial. J Clin Oncol 2002;20:630-637.
15. Viviani S, Zinzani PL, Rambaldi A, et al. ABVD versus BEACOPP for Hodgkin's lymphoma when high-dose salvage is planned. N Engl J Med 2011;365:203-212.

16. Brenner H, Gondos A, Pulte D. Ongoing improvement in long-term survival of patients with Hodgkin disease at all ages and recent catch-up of older patients. Blood 2008;111:2977-2983.

17. Levis A, Anselmo AP, Ambrosetti A, et al. VEPEMB in elderly Hodgkin's lymphoma patients. Results from an Intergruppo Italiano Linfomi (IIL) study. Ann Oncol 2004;15:123-128.

18. Halbsguth TV, Nogova L, Mueller H, et al. Phase 2 study of BACOPP (bleomycin, adriamycin, cyclophosphamide, vincristine, procarbazine, and prednisone) in older patients with Hodgkin lymphoma: a report from the German Hodgkin Study Group (GHSG). Blood 2010;116:20262032.

19. Böll B, Bredenfeld H, Gorgen H, et al. Phase 2 study of PVAG (prednisone, vinblastine, doxorubicin, gemcitabine) in elderly patients with early unfavorable or advanced stage Hodgkin lymphoma. Blood 2011;118:6292-6298.

20. Evens AM, Helenowski I, Ramsdale E, et al. A retrospective multicenter analysis of elderly Hodgkin lymphoma: outcomes and prognostic factors in the modern era. Blood 2012;119:692-695.

21. Proctor SJ, Wilkinson J, Jones G, et al. Evaluation of treatment outcome in 175 patients with Hodgkin lymphoma aged 60 years or over: the SHIELD study. Blood 2012; 119:6005-6015. 


\section{当院におけるホジキンリンパ腫 36 例の臨床的特徵と治療成績の検討}

和泉清隆 ${ }^{1}$, 鴨田吉正 ${ }^{1}$, 飯岡 大 $^{1}$, 前迫善智 ${ }^{1}$, 赤坂尚司 ${ }^{1}$, 本庄 原 $^{2}$, 大野仁嗣 ${ }^{1}$

1 天理よろづ相談所病院 血液内科

2 天理よろづ相談所病院 病理診断部

目的: 当院で診療したホジキンリンパ腫患者の臨床的特徵と治療成績を明らかにするために，カルテレビューによる後 ろ向き研究を行った。

対象患者: 2003 年 1 月から 2012 年 10 月の間に当院でホジキンリンパ腫と診断され，化学療法単独または化学療 法十放射線治療を受けた 36 例について検討した。

結果: 病理診断は, 24 例が結節硬化型， 6 例が混合細胞型であった。年齢は 20 から 81 歳で, 中央值は 61 歳, 年齢分布は二峰性を示し， 18 例が 60 歳以上であった. 8 例は限局期， 28 例は進行期に分類された. International prognosis scoringに従うと，14 例が予後良好群，22 例が予後不良群であった。 29 例がABVd/ABVDレジメンに よる化学療法を受け，7 例が化学療法後に放射線治療を受けた。 23 例 $63.9 \%$ )が完全寛解に二至り，全奏功率は $72.2 \%$ であった。観察期間中央值 3.0 年で, 5 年無増悪生存率は $66.1 \%, 5$ 年全生存率は $75.0 \%$ であった. 60 歳 未満の若年者と 60 歳以上の高齢者を比較すると, 5 年無增恵生存率がそれぞれ $76.2 \%$ と $54.7 \%, 5$ 年全生存率 がそれぞれ $94.1 \%$ と $55.0 \%(P=0.014)$ であった。高齢者が予後不良である原因として，合併症が多いことや，治 療毒性が高いことが考えられた。

考案: 若年者の治療成績はJCOG 9305 試験のそれと同等であった。現時点では，高齢者ホジキンリンパ腫患者に 対してもABVD 療法が標準治療であるが，より毒性の低い治療レジメンを計画する必要があると考えられた．

キーワード: ホジキンリンパ腫，ABVd/ABVDレジメン，治療成績，高齡者，JCOG 9305 試験 